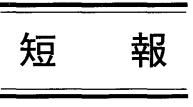

\title{
Signet-ring cell lymphoma の捺印細胞像
}

\author{
弘前大学医学部病理学第 1 講座 ${ }^{1)}$, 青森県立中央病院病理 ${ }^{2}$, 青森市民病院臨床病理部 ${ }^{31}$ \\ 黒滝日出一 ${ }^{1)}$ 菅 三知雄 ${ }^{2)}$ 貝森 光大 ${ }^{21}$ 吉岡 治彦 ${ }^{3)}$ \\ 鎌田 義正 ${ }^{11}$
}

\section{I. はじめに}

Signet-ring cell lymphoma (以下 SRCL と略す)

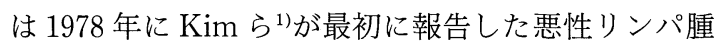
のまれな一亜型で現在まで約 40 例近くの報告例がみ られる. 今回われわれは SRCL の 1 剖検例を経験し, その捺印細胞像を観察する機会を得たので若干の文献 的考察を加えて報告する.

\section{II. 症例}

患 者: 73 歳, 女性

既往歴：特記すべきことなし

主 訴：腹部不快感, 上腹部痛

現病歴：1983 年 2 月頃より腹部不快感と上腹部痛 があったが, 放置していた. 1984 年 9 月に腹部超音 波検查で腹部大動脈を取り囲む $43 \times 17 \mathrm{~mm}$ 大の後腹 膜腫瘤が認められた。針生検にて後腹膜線維症が疑わ れてステロイドが投与された. ステロイド投与にて腫 瘤は縮小傾向を示したが，減量すると増大した。死亡

\footnotetext{
Imprinted cytological findings of signet-ring cell lymphoma

Hidekachi KUROTAKI'), M.D., M.I.A.C., Michio SUGA ${ }^{2)}$, M.D., M.I.A.C., Mitsuomi KAIMORI ${ }^{2}$, M.D., Haruhiko YOSHIOKA $^{3)}$, C.T., J.S.C., Yoshimasa KAMATA ${ }^{1)}$, M.D.

${ }^{1)}$ First Department of Pathology, Hirosaki University School of Medicine

${ }^{2}$ Department of Pathology, Aomori Prefectural Central Hospital

${ }^{3}$ Department of Clinical Pathology, Aomori City Hospital 論文別刷請求先 036 青森県弘前市在府町 5 弘前大学 医学部病理学第 1 講座 黒滝日出一

平成 5 年 5 月 17 日受付

平成 5 年 12 月 18 日受理
}

1 力月前の血液・生化学検査の異常值は WBC $14.9 \times$ $10^{3} / \mathrm{m} l, \mathrm{RBC} 3.22 \times 10^{6} / \mathrm{m} l, \mathrm{Hb} 9.6 \mathrm{~g} / \mathrm{d} l$, T.P. $4.2 \mathrm{~g} / \mathrm{d} l, \mathrm{LDH} \quad 668 \mathrm{IU} / \mathrm{L}, \mathrm{BUN} 46 \mathrm{mg} / \mathrm{d} l$, Creatinin $1.8 \mathrm{mg} / \mathrm{d} l$ であった。免疫グロブリンの定 量や電気泳動などの検査は施行されなかった。 1991 年 4 月 29 日心不全, 腎不全をきたして死亡した.

病理解剖所見 : 腫瘤は, 大きさが $8 \times 5 \times 20 \mathrm{~cm}$ で, 大動脈周囲性に横隔膜下より左右総腸骨動脈まで椎体 前面を縦走性に存在しており，傍大動脈リンパ節は癒 合し一塊となり巻き込まれていた。滑面は平滑で充実 性灰白色を呈し, 出血, 壊死は認められなかった. 胃 および小腸，大腸には腫場はなかった。転移および浸 潤は心臓, 左肺, 胸膜に認められた。左右腎は貯留囊 胞が多数あり，動脈硬化性萎縮腎の所見を呈してお り, 間質には鬱血および浮腫も認められ, 心臓への広 範な腫瘍の転移浸潤による心機能不全が重要な因子と 考えられた。

病理組織所見 : 後腹膜腫瘍は N/C 比の大きな小型 の類円細胞と細胞質に好酸性封入体をもつ SRC のび まん性増殖からなった。核には小型ながら明瞭な核小 体が $1 \sim 2$ 個と, 核縁の軽度のくびれが特徵的であっ た. SRCの細胞質はPAS, Alcian blue, おょび pyronin染色陰性であった。免疫組織染色（Streptavidin-Biotin 法) では LCA，L 26，L N 1 が SRC も含む腫瘍細胞に陽性を示し， $\lambda$ が SRC の細胞質に 陽性に染色された。 AE 1/AE 3 (keratin), vimentin, desmin, IgG, IgM, IgA おょび べて陰性であった。

腫瘍の捺印細胞像：パパニコロー染色では，細胞の 大部分は類円形の裸核およびライトグリーンに濃染す る封入体を特徵とする偏在核細胞からなった（写真 1).ギムザ染色では核のクロマチン網は繊細で, 封 


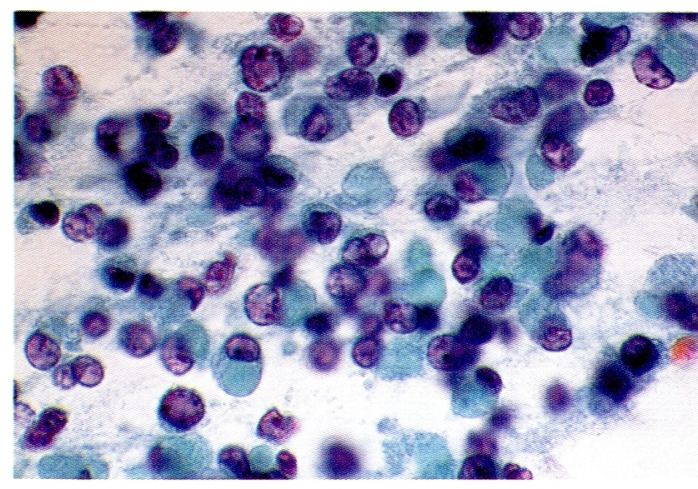

写真 $1 \mathrm{~N} / \mathrm{C}$ 比大で核にくびれを有する lymphoid cell と核が 偏在しライトグリーンに好染する core 状の封入体を細 胞質に有する SRC が混在してみられる（パパニコロー 染色，対物 $\times 100)$

入体は好塩基性に染まった（写真 2$)$.パパニコロー 染色標本を脱色後酵素抗体法にて SRC を含む腫瘍細 胞にL 26 が，SRCの細胞質に $\lambda$ が陽性を示した。

\section{III. 考察}

SRCL は 50 歳以上に多く発生し，女性にやや多い 傾向がある. 発生部位はリンパ節原発が $75 \%$ 以上を 占め，再発もしくは死亡例はごくわずかで予後良好と されているが，症例数が少なく，このタイプにおける 明確な natural history や biological behavior は明ら かにされて抢らず，分類に扮ける位置づけも決定され ていない。われわれの症例では後腹膜に腫瘤が発見さ れてから約 7 年後に死亡したが，剖検時心臓，肺など に転移がみられたが骨髄浸潤はなかった。Kim ら SRCL clear, vacuolated type $と$ eosinophilic, Russell body type の 2 型に分類している. clear type は細胞質内に空胞を有し，PAS 反応陰性，eosinophilic type は細胞質内に Russell 小体様の封入体を有 し，PAS 反応陽性を示す。われわれの症例はPAS 反 応陰性であったが eosinophilic type に属すると考元 られた．SRC様を呈し鑑別を要する疾患としては腺 癌 (特に印環細胞癌) ${ }^{1)}$, 脂肪肉腫 ${ }^{2}$ などが報告されて いる．近年悪性リンパ腫の予後は腺癌と比較すると格 段良くなっており，正確な診断が細胞診で得られれば

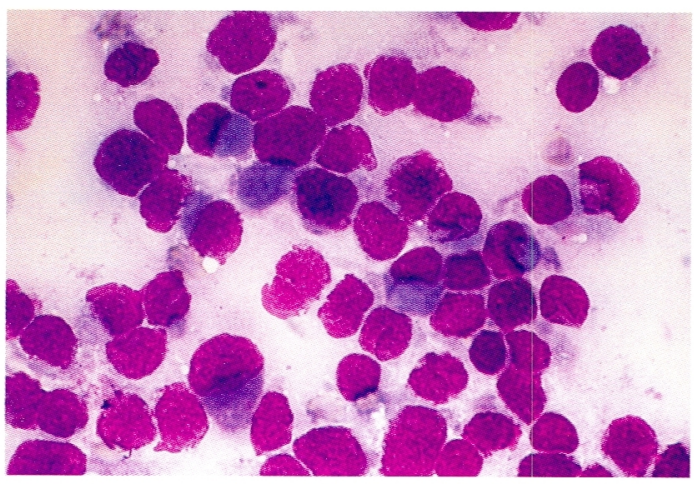

写真 2 lymphoid cell とともに弱好塩基性の細胞質を有する細 胞がみられる（ギムザ染色，対物 $\times 100 ）$

患者の治潦および予後に貢献できると考えられる. PAS 反応陽性の SRCL では特に印環細胞癌と鑑別が 必要であるが， SRC 以外に N/C 比大，核にくびれな どの不整があり，クロマチンの瀻細な lymphoid cell の孤立散在性出現に注目しても鑑別がかなり困難であ る、したがって, 今回の症例のようにパパニコロー染 色標本を脱色し酵素抗体法で免疫グロブリンを染色す ることは SRCL の eosinophilic type の確定診断へ到 達する良い補助診断になると思われる。また，三浦

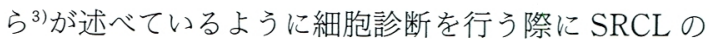
ような悪性リンパ腫の一亜型があることを頭の片隅に とどめておくことも必要であろう。

\section{文献}

1) Kim, H., Dorfman, R.F., Rappaport, H. : Signet ring cell lymphoma. A rare morphologic and functional expression of nodular (follicular) lymphoma, Am. J. Surg. Pathol., $2: 119 \sim 132,1978$.

2) Mathur, D.R., Ramdeo, I.N., Sharma, S.P., et al. : Signet ring cell lymphoma simulating liposarcoma. A case report with brief review of literature, Indian J. Cancer, 25: 52 55, 1988 .

3）三浦弘資，小池美貴男，藤原さおり：腹水中に Russell 小体様の封入体をもつ異型細胞が出現した回盲部原発の 悪性リンパ腫の1例，日臨細胞誌，30：1141～1146, 1991 